\title{
Vpliv učiteljevih navodil na učno uspešnost dijakov pri učenju z e-učbeniki
}

\author{
Anja Poznič ${ }^{1}$ in Sonja Pečjak ${ }^{2 *}$ \\ ${ }^{1}$ Rače \\ ${ }^{2}$ Oddelek za psihologijo, Filozofska fakulteta, Univerza v Ljubljani
}

Povzetek: E-izobraževanje, e-učenje in e-učbeniki so pojmi, povezani s sodobnim šolanjem. Interaktivni e-učbeniki predstavljajo učni vir, iz katerega se lahko učenci učinkovito učijo. Učenci, spretni v uporabi tehnologije, niso nujno spretni tudi pri učenju s tehnologijo, ampak pri tem potrebujejo usmeritve. V raziskavi smo s pomočjo eksperimenta preverjali vpliv učiteljevih navodil na učno uspešnost učencev pri učenju z interaktivnim e-učbenikom. V raziskavi je sodelovalo 83 dijakov 1. letnikov dveh gimnazij, od tega $45 \mathrm{v}$ eksperimentalni (ES) in $38 \mathrm{v}$ kontrolni skupini (KS). Dijaki ES, ki so prejeli učiteljeva navodila, kako uporabljati multimedijske in interaktivne elemente e-učbenika, so bili v primerjavi z dijaki KS, ki takšnih navodil niso prejeli, učno uspešnejši. Dijaki ES so se po učenju iz e-učbenika zaznavali kot nekoliko kompetentnejši ter so v nekoliko večji meri uporabljali multimedijske in interaktivne elemente tega učbenika kot njihovi vrstniki iz KS. Raziskava je pokazala, da je samostojno učenje dijakov iz eučbenika lahko uspešnejše, če jih učitelj s pomočjo navodil seznani, kako ga uporabljati.

Ključne besede: elektronski učbeniki, učiteljeva navodila, dijaki, učna uspešnost

\section{The effect of the teacher's instructions on the academic achievement of high school students in learning with e-textbooks}

\author{
Anja Poznič ${ }^{1}$ and Sonja Pečjak ${ }^{2 *}$ \\ ${ }^{1}$ Rače, Slovenia \\ ${ }^{2}$ Department of Psychology, Faculty of Arts, University of Ljubljana, Slovenia
}

\begin{abstract}
E-education, e-learning and e-textbooks are concepts associated with modern education. Interactive e-textbooks represent a learning resource from which students can learn effectively. Even though contemporary students are skilful with technology in general, that does not mean they are skilful with technology based learning and may need guidance with such learning activities. In our research, we conducted an experiment in order to test the impact of teacher's instructions on the academic achievements of high school students in learning with interactive e-textbooks. The study involved 83 high school students in their first year. There were 45 students in the experimental group (EG) and 38 students in the control group (CG). The students from the EG who have received teacher's instructions on how to use multimedia and interactive elements of the e-textbook were more successful at learning than the students from the CG who did not get such instructions. Students of the EG perceived themselves as more competent and they used multimedia and interactive elements of a textbook more often than their peers from the CG. The results showed that students' independent learning from e-textbooks can be more successful if the teacher provides clear instructions on how to use them.
\end{abstract}

Keywords: electronic textbooks, teacher's instructions, students, academic achievement

\footnotetext{
*Naslov/Address: red. prof. dr. Sonja Pečjak, Oddelek za psihologijo, Filozofska fakulteta, Univerza v Ljubljani, Aškerčeva 2, 1000

Ljubljana, e-mail: sonja.pecjak@ff.uni-lj.si
}

Članek je licenciran pod pogoji Creative Commons Attribution 4.0 International licence. (CC-BY licenca).

The article is licensed under a Creative Commons Attribution 4.0 International License (CC-BY license). 
S pojmom e-izobraževanje ali e-učenje označujemo način poučevanja in učenja $\mathrm{z}$ informacijsko-komunikacijsko tehnologijo (IKT). IKT, še posebej računalnik, sta v izobraževanju omogočila številne nove možnosti dostopanja do informacij, organiziranja, analiziranja, predstavitve in izmenjave teh informacij $\mathrm{z}$ učenci in drugimi (McGhee in Kozma, 2001). Poučevanje in učenje z IKT, med drugim tudi z elektronskimi učbeniki, se pogosto povezuje s samostojnejšim delom učencev, kot je to značilno za tradicionalno učno okolje. Skladno s tem pa se spreminja tudi vloga učitelja: od predavatelja in vodje razprave $\mathrm{v}$ tradicionalnem učnem okolju, do novih vlog, kot so oblikovalec e-učnega okolja, trener veščin dela s tehnologijo in svetovalec, ki spremlja in nudi podporo učencem (Ivanišin, 2009).

Spoznanja o učinkovitosti poučevanja in učenja $\mathrm{Z}$ različno IKT še vedno ne dajejo enoznačnih odgovorov (npr. Nishizaki, 2015; Van Horne, Russell in Schuh, 2016). To povzroča zmedenost in zadržke pri učencih in učiteljih, katerim je ta tehnologija v šolah namenjena (Uluyol in Şahin, 2014). Avtorja poudarjata, da so učitelji tisti, od katerih je v prvi vrsti odvisno, ali in v kolikšni meri bodo učenci IKT uporabljali pri učenju, zato je poleg tehnološke opremljenosti šol in dobro oblikovanih e-učnih gradiv pomembno tudi izobraževanje učiteljev o IKT in njeni smiselni uporabi pri pouku.

\section{E-učbenik v primerjavi s klasičnim učbenikom}

Elektronski učbenik ali e-učbenik je bil v svojih začetkih opredeljen kot elektronski učni vir, ki lahko v celoti nadomesti klasični oziroma tiskani medij, za njegovo uporabo pa so potrebna določena tehnična sredstva. Najprej je šlo samo za preslikavo tiskanega učbenika v elektronsko obliko oziroma za njegovo digitalizacijo, dandanes pa e-učbenik opredeljujemo kot kompleksen učni medij, ki je zasnovan tako, da spodbuja aktivne procese učenja na inovativen, posamezniku prilagojen in učinkovit način. Gre namreč za digitalno učno gradivo, kateremu so med besedilom dodani multimedijski in interaktivni elementi, kot so npr. hiperpovezave, videi, različni zvoki in animacije. Tak e-učbenik imenujemo tudi interaktivni ali i-učbenik (Kreuh, Kač in Mohorčič, 2011).

Velikojeraziskav,kiseukvarjajos primerjavoučinkovitosti uporabe klasičnih in e-učbenikov. Izsledki raziskav niso povsem konsistentni, kar gre pripisati preučevanju različnih oblik e-učbenikov (digitaliziranih in interaktivnih), zasledovanju različnih učnih ciljev in izvedb raziskovanja. Raziskovalci v splošnem ugotavljajo, da sta učenje in uspešnost dela z e-gradivom bolj kot od vrste medijev, preko katerih je podana učna snov, odvisna od značilnosti učnega okolja (Daniel in Woody, 2012) in metod poučevanja (Mayer, 2009, 2013). Daniel in Woody (2012) ugotavljata, da naj bi bilo učenje v šoli, ki ga nadzorujejo učitelji, uspešnejše kot učenje doma. Prav tako naj bi bila uspešnost učenja bolj kot od tipa učnega gradiva odvisna od težavnosti učne vsebine in posameznikovega zanimanja zanjo (Ebied in Rahman, 2015; Jones in Brown, 2011), uporabljenih učnih strategij učencev (Núñez idr., 2011; Rutar Leban in Milekšič, 2016), njihovega vsebinskega predznanja (Wells, 2012), izkušenj z različnimi tipi učbenikov (Berg, Hoffmann in Dawson, 2010; Nishizaki,
2015), pa tudi od značilnosti multimedijskih in interaktivnih elementov v e-učbenikih (Jones in Brown, 2011).

T. Rutar Leban in Milekšič (2016) ugotavljata, da eučbenike večina slovenskih učiteljev pri pouku uporablja občasno, največkrat med razlago učne snovi, ko učitelji uporabijo posamezne interaktivne elemente za ilustriranje razlage. Učenci uporabljajo e-učbenike tudi za samostojno delo, največkrat za reševanje nalog, redkeje pa se iz njih doma učijo. Starši učencev zaznavajo, da so njihovi otroci pri delu z e-učbeniki samostojni, a opažajo, da otroci pri učenju in izdelavi domačih nalog pogosteje ali enako pogosto kot po e-učbeniku posežejo po klasičnem učbeniku. Kot ugotavljata avtorja, na tem področju za zdaj še primanjkuje sistematične evalvacije o delu z e-učbeniki in didaktičnih priporočil za uspešno uporabo. Oba omenjena vidika smo poskušali zajeti v naši raziskavi, v kateri smo evalvirali učinkovitost učiteljevih navodil o uporabi multimedijskih in interaktivnih elementov pri samostojnem učenju dijakov iz e-učbenika.

\section{Učitelj, e-učno okolje in uporaba e-učbenikov}

Ivanišin (2009) je ugotovil, da učitelj v tradicionalnem učnem okolju prevzema večino komunikacije in intenzivneje uravnava delovanje učencev. V nasprotju s tem pa je za eučno okolje, $\mathrm{v}$ katerem pouk ali učenje poteka $\mathrm{z}$ uporabo IKT, značilna dejavnejša in bolj izpostavljena vloga učencev. Costley in Lange (2016) pa sta poudarila, da e-učno okolje s podporo učitelja učencem zagotavlja uspešnejše delo in jim daje občutek večje samoučinkovitosti kot tisto brez aktivne vloge učitelja. Pri tem pa so Anderson, Rourke, Garrison in Archer (2001) navedli tri vloge učitelja v e-učnem okolju. Prvo predstavljajo načrtovanje, organizacija in strukturiranje e-učenja. Učitelj lahko oblikuje lastno e-učno gradivo ali pa dostopa do že obstoječega. Ob začetku pouka v e-učnem okolju učitelj predstavi cilje, navede učne metode oziroma predvidene načine dela, določi predviden čas, usmeri učence k izkoriščanju možnosti, ki jih ponuja učni medij, in opozori učence na pričakovano vedenje med učenjem. Druga vloga učitelja je podpora učencem $\mathrm{v}$ procesu učenja, $\mathrm{s}$ katero vzdržuje njihovo zanimanje, motivacijo in učno zavzetost. Tretja vloga učitelja v e-učnem okolju pa je dajanje opore oziroma navodil, ki se navezujejo na vsebino učenja, učno vedenje ali na morebitne tehnične zadeve.

Costley in Lange (2017) sta potrdila, da učitelj, ki v eučnem okolju vstopa $v$ te vloge, učencem omogoča boljše razumevanje učne snovi, hkrati pa so ti učenci bolj naklonjeni nadaljnjemu učenju iz e-gradiv. Pomembna vloga učitelja je, da učence skozi e-učbenik vodi z lastnim modeliranjem ali pa le z ustnimi oziroma s pisnimi navodili (Lipovec, Senekovič in Repolusk, 2014; Poznič in Pečjak, 2017).

Spletne povezave ali multimedijski in interaktivni elementi, ki so del e-učbenikov, lahko podpirajo učenje iz besedila, pri nekaterih učencih pa lahko povzročijo težave v razumevanju (Dobler, 2015). Učenci namreč pogosto prekinjajo učenje z ogledi spletnih strani, na katere jih vodijo hiperpovezave, raznih videov in prikazov simulacij. Avtorica je navedla, da to ni vedno najučinkovitejše, saj učenci s tem izgubljajo »rdečo nit«. To lahko prepreči učitelj s podporo učencem v obliki ustnih oziroma pisnih navodil, kot je bilo 
tudi v naši raziskavi. Belland (2017) je navedel različne podpore učitelja: konceptualne (učencu dajejo namige o vsebini in ključnih pojmih), strateške (učitelj daje navodila učencem, kako se lotiti učinkovitega učenja, npr. katere učne strategije uporabiti), metakognitivne (učenec dobi namige, kako načrtovati, spremljati in evalvirati svoje delo) ali motivacijske (to so učiteljevi namigi za vzdrževanje učenčeve motivacije in pripravljenosti vlagati trud $\mathrm{v}$ učenje). Vsa ta podpora učencem pomaga pri upravljanju z multimedijskimi in interaktivnimi elementi besedil v e-učbeniku z namenom učinkovitejšega učenja.

Predstavljena podpora oziroma koraki dela z e-učbenikom so prav tako skladni z elementi poučevanja, kot sta jih navedla Gagné in Medsker (1996), in so znani kot del Gagnéjeve teorije poučevanja. Učitelj ali e-učno gradivo samo po sebi naj bi po tej teoriji zasledoval/-o devet elementov učinkovitega poučevanja: pridobitev pozornosti učencev, predstavitev učnih ciljev, priklic predznanja učencev, predstavitev nove učne vsebine, usmerjanje učencev skozi pridobivanje in usvajanje novega znanja, vajo, dajanje povratnih informacij o naučenem, ugotavljanje novega znanja ter spodbujanje zapomnitve in transfer znanja. F. Leow in M. Neo (2014) trdita, da so uporabniki ob kakovostnem e-učnem gradivu, oblikovanem s temi devetimi elementi, sposobni samostojno predelati učno snov in izkusiti prednost lastnega tempa učenja.

\section{Značilnosti učencev pri učenju iz e-učbenikov}

Cilj učiteljevega dela $\mathrm{z}$ učenci pri učenju z e-učeniki je predvsem učence usposobiti za samostojno učenje iz eučbenikov v razredu ali doma. Ob poučevanju z e-učbeniki pa morajo biti učitelji pozorni tudi na številne značilnosti učencev, ki se povezujejo z uspešnostjo učenja. Najprej so to učenčeve predhodne izkušnje $\mathrm{z}$ e-učbeniki oziroma poznavanje dela $\mathrm{z}$ e-učbeniki ali e-gradivom na splošno. A. Lipovec idr. (2014) poudarjajo, da lahko učitelj zagotovi uspešnejše učenje iz egradiva s kratkimi, razumljivimi in nedvoumnimi navodili o načinu učenja iz e-gradiva. Učitelji namreč pogosto sklepajo, da so učenci, ki so vešči upravljanja s klasičnimi učbeniki in tehnologijo na splošno, prav tako vešči upravljanja $\mathrm{z}$ eučbeniki. Zadnje ne drži nujno, zato so v veliko pomoč opore oziroma navodila učitelja za delo s temi učbeniki, še posebej v zgodnjih fazah dela s tovrstnim gradivom (Van Horne idr., 2016). P. Luik in Mikk (2008) sta pri 15- in 16-letnih dijakih potrdila, da so imeli učno uspešnejši dijaki pri učenju iz egradiv več izkušenj (računalniških in s spletom) in da so se opisali tudi kot bolj računalniško kompetentni. Pri tem se je pokazalo, da so bile različne navigacijske smernice o tem, kako uporabljati e-učbenik, pomembnejše za računalniško manj izkušene dijake. Podobno sta Poznič in Pečjak (2017) ugotovili pri 16 letnih dijakih, da so bili učno najbolj uspešni pri učenju iz e-učbenika tisti, ki so imeli vsaj nekaj preteklih izkušenj s temi učbeniki in so hkrati prejeli učiteljičina navodila o delu z e-učbenikom. Najslabši učni rezultat pa so imeli dijaki brez predhodnih izkušenj z e-učbeniki, ki niso prejeli navodil učiteljice. Tudi Nishizaki (2015) je poročal o tem, da je izkušenost dela $\mathrm{z}$ e-gradivom pomemben napovednik učne uspešnosti učencev.
Pomemben element učinkovitega e-učenja je tudi predznanje učencev. Tako so npr. Mayer, A. Mathias in K. Wetzell (2002) ugotovili, da so bili učenci, ki so pred eučenjem slišali razlago ključnih pojmov iz e-gradiva, pri učenju učno uspešnejši od tistih, ki te razlage niso bili deležni. Gegenfurtner, Lehtinen in Säljö (2011) pa so v metaanalitični študiji ugotovili, da so učenci z več predznanja sposobni iz e-gradiva hitreje pridobivati informacije, bolje zaznavati pomembne in izločati nepomembne informacije kot tisti $\mathrm{z}$ manj predznanja.

Tudi večja naklonjenost učenju z e-učbeniki naj bi bila dejavnik učinkovitejšega e-učenja. Cakir in Solak (2014) sta pokazala, da se pozitivnejša stališča študentov do e-učnih gradiv, izražena skozi manjši odpor do teh gradiv, povezujejo z njihovo večjo učno uspešnostjo. O enaki pozitivni povezanosti naklonjenosti delu z e-učbeniki in učne uspešnosti sta poročala tudi P. Luik in Mikk (2008) pri dijakih.

Študije učinkovitega učenja poudarjajo še en dejavnik učne uspešnosti učenja s klasičnimi gradivi in z e-gradivi, in sicer veščine samoregulacijskega učenja (Berg idr., 2010; Dobler, 2015; Zimmerman, 2002). Núñez s sodelavci (2011) je ugotovil, da so posamezniki, ki poznajo različne učne strategije (kognitivne, metakognitivne in motivacijske strategije ter strategije upravljanja $\mathrm{z}$ viri) in jih pri samostojnem učenju uporabljajo pogosteje, učno uspešnejši. Nekatere raziskave (Lawanto, Santoso, Goodridge in Lawanto, 2014; Mbarek in El Gharbi, 2013) so preučevale povezanost posamičnih učnih strategij z uspešnostjo pri e-učenju in ugotovile enako. Študija avtorjev Shih in J. Gamon (2002) pa kaže, da lahko z učnimi strategijami pojasnimo kar 25 odstotkov variance učne uspešnosti učencev pri e-učenju.

\section{Namen in cilji raziskave}

Raziskave kažejo, da so pomembni dejavniki učne uspešnosti učencev pri tradicionalnem učenju in e-učenju poleg značilnosti učencev tudi spodbudno šolsko okolje in strategije poučevanja v njem (Mbarek in El Gharbi, 2013; Song in Kang, 2012). Dozdajšnje raziskave uspešnosti učenja iz egradiv sicer že ugotavljajo učinkovitost učiteljevih navodil in različnih opor (Belland, 2017; Jones in Brown, 2011; Luik in Mikk, 2008; Nishizaki, 2015), vendar njihov vpliv še ni dobro raziskan. Zato smo v naši študiji želeli raziskati vlogo strateških opor učitelja (Belland, 2017) ob hkratnem nadzoru nekaterih najpomembnejših dejavnikov učencev, ki določajo njihovo učno uspešnost pri e-učenju.

Namen naše raziskave je bil ugotoviti, ali učiteljeva natančna in strateška navodila o spretni uporabi interaktivnega e-učbenika ter njegovih multimedijskih in interaktivnih elementov pri učenju (npr. hiperpovezav, animacij) pomagajo dijakom k uspešnejši uporabi učbenika, s tem pa k boljšemu razumevanju učne snovi oziroma boljšim učnim dosežkom. Predpostavljali smo, da bodo dijaki eksperimentalne skupine, ki so dobili natančna navodila učitelja, kako uporabljati multimedijske in interaktivne elemente, po samostojnem učenju pokazali boljše razumevanje učne snovi. 


\section{Metoda}

\section{Udeleženci}

V raziskavi so sodelovali štirje oddelki dijakov 1. letnikov dveh splošnih slovenskih gimnazij in dve učiteljici geografije. Vzorec je predstavljalo 83 dijakov, od tega $33 \%$ fantov in 67 $\%$ deklet. Dijaki so bili razdeljeni v eksperimentalno (ES) in kontrolno skupino (KS). Skupaj je bilo v ES 45 dijakov (31 $\%$ fantov in $69 \%$ deklet), v KS pa 38 dijakov (34\% fantov in $66 \%$ deklet). Na vsaki gimnaziji smo iz dveh oddelkov dijakov oblikovali po en oddelek ES in en oddelek KS, tako da smo dijake obeh oddelkov posamezne gimnazije med seboj pomešali. Dijaki so bili razdeljeni v obe skupini glede na določene predhodno ugotovljene značilnosti (npr. predznanje, izkušnje z učenjem iz e-gradiv itn.), ki smo jih uporabili kot kriterije za izenačitev skupin. Vsaka izmed učiteljic je na svoji gimnaziji poučevala dijake ES in KS. Neenako število dijakov v obeh skupinah je bilo posledica osipa dijakov pri učni uri samostojnega učenja iz e-gradiva. Zastopanost dijakov v ES in KS se glede na spol ni pomembno razlikovala, $\chi^{2}(1)=0,09$, $p=0,76$. Povprečna starost dijakov je bila 15,7 leta $(S D=$ 0,31 ). Vsi sodelujoči dijaki so 1 . letnik gimnazije obiskovali prvič. Podatki, pridobljeni na tem vzorcu, so bili uporabljeni tudi v raziskavi Poznič in Pečjak (2017).

\section{Pripomočki}

Za zbiranje podatkov o značilnostih učencev, ki so nam služili kot kriteriji za izenačitev ES in KS, smo pred izvedbo eksperimenta uporabili naslednje pripomočke:

Vprašalnik motivacijskih prepričanj in učnih strategij. MSLQ (angl. Motivated Strategies for Learning Questionnaire; Pintrich, Smith, Garcia in McKeachie, 1991)je samoocenjevalni vprašalnik za merjenje dijakove motivacije in uporabe učnih strategij pri specifičnem šolskem predmetu. Originalni vprašalnik ima 81 postavk in dve lestvici - lestvico motivacijskih prepričanj (s šestimi podlestvicami) in lestvico učnih strategij (z devetimi podlestvicami). Za potrebe naše raziskave smo v vprašalnik za dijake vključili le 57 postavk, ki so služile namenu raziskave. Od lestvice motivacijskih prepričanj smo vključili podlestvice: notranja motivacijska usmerjenost, pripisovanje vrednosti snovi, samoučinkovitost in testna anksioznost. Od lestvice učnih strategij pa smo vključili podlestvice: ponavljanje, elaboracija, organizacija, metakognicija in regulacija napora. Postavke smo prilagodili za preverjanje motivacijskih prepričanj in učnih strategij dijakov pri pouku geografije. Dijaki so na 5-stopenjski lestvici (1 - nikakor ne velja zame, 5 - povsem velja zame) ocenjevali strinjanje s posamezno trditvijo. Pri obdelavi naših podatkov smo upoštevali priporočila raziskav, ki so preverjale konstruktno veljavnost originalnega vprašalnika na večjem vzorcu, kot je bil naš (Cho in Summers, 2012; Credé in Phillips, 2011; Hilpert, Stempien, van der Hoeven Kraft in Husman, 2013), saj nam je naš vzorec dopuščal le preliminarno analizo strukture uporabljenega instrumenta. Omenjene raziskave so ugotovile, da lahko ločeno analiziramo in prikažemo skupen rezultat vseh podlestvic motivacijskih prepričanj (razen podlestvice testne anksioznosti, ki se prikazuje ločeno) in skupen rezultat lestvice učnih strategij. Tako dobljena 3-faktorska struktura vprašalnika je izkazala ustrezno zanesljivost tudi na naših podatkih. Prvi faktor - motivacijska prepričanja - je združeval notranjo ciljno motivacijsko usmerjenost, pripisovanje vrednosti snovi in samoučinkovitost $(\alpha=0,90)$; drugi faktor - učne strategije - je predstavljal skupno lestvico učnih strategij $(\alpha=0,84)$; tretji faktor pa je bila podlestvica testne anksioznosti $(\alpha=$ $0,70)$. Natančnejši postopek analize in dobljenih faktorjev je predstavljen v magistrskem delu A. Poznič (2016).

Vprašalnik stališč do uporabe e-učbenika. Za potrebe preverjanja stališč dijakov do uporabe e-učbenika smo oblikovali lastni vprašalnik, ki je imel 16 postavk. Pri sestavi postavk smo si pomagali s spoznanji raziskav, ki so preverjale prednosti in slabosti učenja $\mathrm{z}$ e-učbeniki $\mathrm{v}$ primerjavi $\mathrm{S}$ klasičnimi učbeniki (Daniel in Woody, 2012; RockinsonSzapkiw, Courduff, Carter in Bennett, 2013). Pri vsaki postavki (kot npr. Učenje iz tiskanega učbenika je lažje kot učenje iz besedil na računalniku ali tablici.) so dijaki odgovarjali na 5stopenjski lestvici, koliko se strinjajo s trditvijo (1 - nikakor se ne strinjam, 5 - popolnoma se strinjam).

$\mathrm{Na}$ podatkih 83 dijakov smo izvedli faktorsko analizo po metodi glavnih osi in s poševnokotno rotacijo dobili 2faktorsko strukturo vprašalnika (Poznič, 2016), pri čemer smo izločili 6 postavk, ki so nasičale oba faktorja. Prvi faktor je predstavljal mero naklonjenosti e-učbenikom (6 postavk), drugi pa mero naklonjenosti klasičnim učbenikom (4 postavke). Zanesljivost obeh faktorjev je bila ustrezna (Cronbach $\alpha$ prvega faktorja je znašal 0,83, drugega pa 0,85). Koeficient korelacije med faktorjema je bil $r_{s}=-0,54, p<$ 0,001 .

Vprašalnik o izkušnjah učenja iz e-gradiv. $Z$ vprašalnikom s 6 postavkami smo preverili, koliko izkušenj imajo dijaki z učenjem iz e-gradiv. Zanimala nas je pogostost naslednjih aktivnosti oz. učenja s pomočjo tehnologije in svetovnega spleta: i) učenje iz e-učbenikov; ii) iskanje vsebin za seminarske naloge; iii) iskanje vsebin, slik in videov za predstavitve; iv) iskanje pomoči pri pisanju domačih nalog; v) iskanje dodatne razlage pri učenju; vi) razjasnitev neznanih pojmov. Dijaki so glede pogostosti dela $\mathrm{z}$ e-gradivi odgovarjali na 5-stopenjski lestvici (od 1 - nikoli do 5 - 2krat tedensko ali pogosteje). Za namen oblikovanja skupne mere izkušenj $\mathrm{z}$ e-gradivi smo uporabili metodo glavnih komponent. Po Kaiser-Guttmanovem kriteriju in grafu drobirja bi lahko izločili dve komponenti. Prva komponenta je pojasnila $46,2 \%$ variance, druga pa $22,9 \%$ variance. Po analizi obeh komponent smo se zaradi slabših karakteristik druge komponente odločili za izločitev ene komponente, ki smo jo poimenovali izkušnje učenja iz e-gradiv. Povprečje uteži te komponente je znašalo $0,24(\min =0,16, \max =0,31)$. Koeficient zanesljivosti komponente, izračunan na osnovi komponentnih točk, je znašal 0,77.

Preizkus predznanja dijakov o temeljnih pojmih, potrebnih za razumevanje izbrane učne enote iz e-učbenika za geografijo, smo preverili z lastnim preizkusom, ki je imel 16 nalog. Sestavljen preizkus sta pred uporabo pregledali in dopolnili tudi učiteljici geografije. Vprašanja so bila povezana $\mathrm{z}$ vsebino učne enote $\mathrm{z}$ naslovom Vodovje - sestava hidrosfere in kroženje vode $v$ naravi in so bila na prvih treh 
ravneh Bloomove taksonomije: poznavanje, razumevanje in uporaba (Anderson in Krathwohl, 2001). Pri tem smo izhajali iz dejstva, da je bilo za učenje izbrane učne enote potrebno le osnovno predznanje (glej tudi Hwang, Chen in Huang, 2016). Čas preverjanja predznanja je bil 20 minut, dijak pa je lahko dobil največ 36 točk.

Vprašalnik o učni izkušnji in upravljanju $z$ eučbenikom. Vprašalnik o učni izkušnji in upravljanju z eučbenikom je bil kratek samoocenjevalni vprašalnik, ki so ga izpolnili dijaki po učenju izbrane učne enote. Na 5-stopenjski lestvici od 1 -nikakor ne velja zame do 5 -povsem velja zame so se opredelili glede zanimivosti učne snovi (Učna snov se mi je zdela zanimiva.), težavnosti snovi (Učna snov se mi je zdela težka za razumevanje.) ter zaznane uspešnosti na preizkusu znanja (Menim, da sem bil/-a na testu znanja uspešen/ uspešna.). Poleg tega so dijaki na isti lestvici označili, koliko pozornosti so namenili naslednjim štirim multimedijskim in interaktivnim elementom oziroma koliko so jih uporabljali med učenjem: i) pojmom $\mathrm{v}$ krepkem tisku in obarvanim pojmom; ii) slikam in podatkom, ki so se prikazali s klikom; iii) slikam, karti in prikazom procesov (simulacijam); iv) podatkom, vprašanjem in nalogam v barvnih okvirjih. Dijak je lahko v delu vprašalnika o upravljanju z multimedijskimi in interaktivnimi elementi dobil največ 20 točk.

Po učenju smo učno uspešnost dijakov preverili $\mathrm{S}$ preizkusom znanja po učenju iz e-učbenika. Pri sestavi nalog tega preizkusa smo izhajali iz učnega načrta predmeta geografije za gimnazije in učnih ciljev, ki naj bi jih s predelavo izbrane učne enote dijaki dosegli. Preizkus znanja je obsegal 10 nalog štirih zahtevnostnih ravni po Bloomovi taksonomiji: poznavanje, razumevanje, uporaba in analiza (Anderson in Krathwohl, 2001). Ponovno smo preverjali le osnovno znanje, saj je bil eksperiment kratek (trajal je le eno šolsko uro), s tem pa je bilo tudi malo časa za učenje. Ob tem smo vendarle želeli, v nasprotju s preizkusom predznanja, oceniti znanje dijakov na višji ravni - ravni analize, kar priporočajo avtorji Ballera, Lukandu in Radwan (2014) ter Hwang idr. (2016). Dijak je lahko dobil največ 32 točk. Tudi preizkus znanja po samostojnem učenju sta pred uporabo pregledali in dopolnili učiteljici geografije. Pri tem so oba preizkusa (tudi preizkus predznanja pred eksperimentom) dijaki reševali v papirnati obliki.

\section{Postopek}

Najprej smo oblikovali terenski eksperimentalni raziskovalni načrt, v katerem je bila neodvisna spremenljivka prisotnost navodil učiteljic o tem, kako uporabljati e-učbenik $\mathrm{z}$ vsemi njegovimi multimedijskimi in interaktivnimi elementi. Navodila so bila dana le dijakom v ES, ne pa tudi v $\mathrm{KS}$, odvisno spremenljivko pa je predstavljal rezultat dijakov na preizkusu znanja po samostojnem učenju iz e-učbenika. Pred eksperimentom smo načrt najprej predstavili obema učiteljicama in dijakom ter pridobili obveščena soglasja dijakov.

Kot kriterije za izenačitev dijakov v ES in KS smo vključili različne dejavnike, za katere predhodne študije kažejo, da so povezane $\mathrm{z}$ učno uspešnostjo dijakov (glej podpoglavje Značilnosti učencev pri učenju iz e-učbenikov $\mathrm{v}$ teoretičnem uvodu). Izenačitveni kriteriji so bili: motivacijska prepričanja dijakov v povezavi z učenjem, testna anksioznost, uporaba učnih strategij pri učenju, stališča dijakov do učenja $z$ e- in klasičnimi učbeniki, učne izkušnje dijakov z e-gradivi ter njihovo predznanje iz geografije.

$\mathrm{V}$ raziskavi smo uporabili prostodostopni e-učbenik za geografijo v 1. letniku gimnazij. Izbrana je bila učna tema Vodovje, znotraj nje pa podtema Sestava hidrosfere in kroženje vode $v$ naravi. Učna snov je na petih straneh eučbenika (strani 149-154).

Za izvedbo eksperimenta smo sestavili natančna didaktična navodila za učiteljici o izvedbi učne ure. Vsem dijakom v ES in KS sta učiteljici na začetku učne ure predstavili učno snov ter jih seznanili s potekom učne ure in z učnimi cilji, ki naj bi jih dosegli. Sledila je seznanitev dijakov o spletnem mestu učne enote, njenem obsegu in o času predelave te enote. Dijaki ES pa so poleg tega dobili še navodilo učiteljic o tem, kako čim bolj spretno uporabljati multimedijske in interaktivne dele e-učbenika. Dijaki ES so bili usmerjeni k temu, da naj več pozornosti namenijo i) pojmom v krepkem tisku in obarvanim pojmom s poudarkom, da naj skušajo te pojme razumeti; ii) slikam in podatkom, ki se prikažejo s klikom (npr. karti o ekološkem stanju voda v Sloveniji); iii) simulacijam, ki prikazujejo procese (npr. kroženje vode $\mathrm{v}$ naravi), dobili so tudi navodilo, naj poskušajo to povezati $\mathrm{z}$ besedilom; iv) podatkom, vprašanjem in nalogam v barvnih okvirjih (npr. razmislek o povezanosti globalnega segrevanja, gladine morja in deleža slane vode). Omenjena navodila učiteljic sodijo v sklop strateških in metakognitivnih opor (Belland, 2017), pri čemer so jih dijaki ES imeli ves čas na voljo na tabli s pomočjo diaprojekcije. Dijaki iz KS teh dodatnih navodil niso dobili in jih niso imeli na voljo na tabli. Edina skupna navigacijska usmeritev, ki so jo prejeli dijaki obeh skupin, je bilo navodilo o premikanju med stranmi eučbenika s pomočjo gumbov na spodnji strani učbenika - levi gumb za premik nazaj in desni za premik naprej.

Dva dni pred izvedbo eksperimenta smo pri dijakih izvedli preizkus predznanja iz geografije, s pomočjo vprašalnikov pa smo dobili podatke o njihovih motivacijskih prepričanjih, testni anksioznosti in učnih strategijah, stališčih do uporabe e- in klasičnega učbenika ter o njihovih učnih izkušnjah z e-gradivi. Dijake smo glede na te rezultate/spremenljivke na vsaki šoli razdelili v ES in KS. Skupno smo torej imeli dve ES in dve KS. Pri razporeditvi dijakov v ES in KS smo izpeljali postopek neposrednega izenačevanja skupin, ki predpostavlja, da sta bili ES in KS dijakov iz obeh šol med seboj čim bolj izenačeni $\mathrm{v}$ pomembnih spremenljivkah za učni dosežek oziroma, da med skupinama ni bilo statistično pomembnih razlik. Zaradi večjega osipa dijakov, razvrščenih v KS, se je na dan izvedbe eksperimenta pojavila razlika $\mathrm{v}$ številčnosti obeh skupin. Zato smo enakost ES in KS pred nadaljnjo analizo podatkov ponovno preverili s statističnimi testi.

V eksperimentu je imel vsak dijak na voljo svoj računalnik, na katerem je bila že odprta izbrana učna enota iz e-učbenika. Dijaki ES in KS so se iz učne enote učili samostojno 20 minut. Pri tem so prejeli tudi prazne liste, če so želeli iz učne enote kaj izpisati. Po 20 minutah učenja so dijaki prejeli preizkus znanja. Tega so lahko reševali ob odprtem e-učbeniku, pri čemer je tudi reševanje preizkusa znanja trajalo 20 minut. 


\section{Rezultati}

Pred začetno obdelavo dobljenih podatkov smo preverili normalnost porazdelitve spremenljivk. Shapiro-Wilkov test normalnosti porazdelitve je v ES in KS pokazal normalno porazdelitev spremenljivk testna anksioznost, učne strategije, naklonjenost e-učbenikom, izkušnje učenja iz e-gradiv in učna uspešnost. Spremenljivke motivacijska prepričanja, naklonjenost klasičnim učbenikom, predznanje dijakov in uporaba elementov e-učbenika pa so pomembno odstopale od normalne porazdelitve (tabela 1 in tabela 2), zaradi česar smo uporabili neparametrične teste. Pred nadaljnjo analizo podatkov smo preverili izenačenost dijakov obeh skupin v spremenljivkah s pomočjo Studentovega $t$-testa pri spremenljivkah, ki so se porazdeljevale normalno, in MannWhitneyjevega $U$-testa pri spremenljivkah $\mathrm{z}$ nenormalno porazdelitvijo (tabela 1).

Iz tabele 1 lahko pri večini spremenljivk, ki so služile kot kriterij za izenačitev skupin, opazimo manjše razlike v povprečnih vrednostih med dijaki ES in KS. Nekoliko večja razlika se pojavlja le pri učnih strategijah, ki naj bi jih po lastnem poročanju v nekoliko večji meri uporabljali dijaki ES. Statistični izračuni preverjanja razlik med skupinama pa so pokazali, da nobena izmed teh razlik ni bila statistično pomembna. Največja je bila omenjena razlika v uporabi učnih strategij v prid dijakov ES, ki je bila blizu meje statistične pomembnosti. Glede na rezultate statističnih testov lahko sklenemo, da smo po postopku neposrednega izenačevanja skupin ES in KS uspeli izenačiti v ključnih spremenljivkah (kot izhaja iz empiričnih študij - glej teoretični uvod), ki so služile kot kriterij izenačevanja skupin. Zato smo predpostavljali, da bi morebitne razlike $\mathrm{v}$ učni uspešnosti med skupinama po eksperimentu lahko $\mathrm{z}$ veliko verjetnostjo pripisali eksperimentalni spremenljivki, tj. natančnim navodilom, ki so jih od učiteljic dobili dijaki ES.
Odvisna spremenljivka v eksperimentu je bila učna uspešnost dijakov, izražena z dosežkom na preizkusu znanja po učenju iz e-učbenika. Razliko v učni uspešnosti smo preverili $\mathrm{s}$ Studentovim $t$-testom enakosti povprečij, prikazanim $\mathrm{v}$ tabeli 2. Pokazalo se je, da so se natančna navodila učiteljic v ES odrazila v večji učni uspešnosti dijakov te skupine. Dijaki ES so namreč statistično pomembno bolje razumeli učno snov kot dijaki KS. Vrednost mediane pri dijakih ES je bila za 2,59 točke višja kot pri dijakih KS ob skoraj enakem interkvartilnem razmiku v obeh skupinah. Pri tem so imela natančna navodila učiteljic o rabi multimedijskih in interaktivnih elementov v e-učbeniku na razumevanje učne snovi dijakov srednje velik učinek. $\mathrm{Z}$ navodili učiteljic lahko pojasnimo približno $7 \%$ variance $v$ razumevanju učne snovi med dijaki obeh skupin.

Primerjava dijakov ES in KS glede uporabe elementov e-učbenika, na katere sta učiteljici dijake ES še posebej opozorili, v tabeli 2 kaže, da so dijaki te skupine v samo nekoliko večji meri uporabljali omenjene elemente kot njihovi vrstniki v KS. Pri tem pa je Mann-Whitneyjev $U$-test pokazal, da razlika med skupinama ni bila statistično pomembna, koeficient velikosti učinka pa zanemarljiv. Poleg tega se količina uporabe multimedijskih elementov e-učbenika ni pomembno povezovala $\mathrm{z}$ učno uspešnostjo dijakov niti pri celotnem vzorcu $(r s=0,03, p=0,81)$ niti pri posameznih skupinah $\left(r_{s}=-0,10, p=0,56\right.$ pri ES in $r_{s}=0,10, p=0,58$ pri KS).

Razlika v uporabi elementov e-učbenika med obema skupinama dijakov je očitnejša ob prikazu razpršenosti dosežkov na tej spremenljivki. Pri ES je bila najnižja vrednost upravljanja z elementi e-učbenika 11 točk, najvišja pa 19 točk, pri KS pa je bil razpon od 8 do 20 točk. Prvi kvartil je pri ES znašal 12,54 točke, pri KS pa 12,45 točke; mediana je bila pri ES 14,08 in pri KS 14,00 točke; tretji kvartil je bil pri ES 16,20 točke, pri KS pa 15,67 točke.

Tabela 1. Opisne statistike in analiza izenačenosti dijakov ES in KS v spremenljivkah za izenačitev skupin

\begin{tabular}{|c|c|c|c|c|c|c|c|c|c|c|}
\hline & & $N$ & $M / M d n$ & $S D / I Q R$ & $A s$ & $S p l$ & $S-W$ & Test & $p$ & $r$ \\
\hline \multirow{2}{*}{$\begin{array}{l}\text { Motivacijska } \\
\text { prepričanja }\end{array}$} & ES & 45 & $69,50^{\mathrm{b}}$ & $13,08^{\mathrm{b}}$ & $-0,87$ & 2,45 & 0,02 & $U=829,50$ & \multirow{2}{*}{0,82} & \multirow{2}{*}{0,03} \\
\hline & $\mathrm{KS}$ & 38 & $66,22^{\mathrm{b}}$ & $9,00^{\mathrm{b}}$ & $-1,13$ & 2,31 & 0,00 & $Z=-0,23$ & & \\
\hline \multirow{2}{*}{ Testna anksioznost } & ES & 45 & 13,62 & 4,19 & 0,32 & $-0,06$ & 0,21 & \multirow{2}{*}{$t(81)=-1,27$} & \multirow{2}{*}{0,21} & \multirow{2}{*}{0,14} \\
\hline & KS & 38 & 14,79 & 4,15 & 0,52 & $-0,46$ & 0,10 & & & \\
\hline \multirow{2}{*}{ Učne strategije } & ES & 45 & 104,36 & 14,01 & $-0,20$ & $-0,19$ & 0,41 & \multirow{2}{*}{$t(81)=1,72$} & \multirow{2}{*}{0,09} & \multirow{2}{*}{0,35} \\
\hline & KS & 38 & 98,97 & 14,47 & 0,18 & $-0,48$ & 0,75 & & & \\
\hline \multirow{2}{*}{$\begin{array}{l}\text { Naklonjenost e- } \\
\text { učbenikom }\end{array}$} & ES & 45 & 16,31 & 5,22 & 0,30 & 0,45 & 0,31 & \multirow{2}{*}{$t(81)=-0,68$} & \multirow{2}{*}{0,50} & \multirow{2}{*}{0,08} \\
\hline & $\mathrm{KS}$ & 38 & 17,08 & 4,96 & 0,83 & 0,78 & 0,06 & & & \\
\hline \multirow{2}{*}{$\begin{array}{l}\text { Naklonjenost } \\
\text { klasičnim učbenikom }\end{array}$} & ES & 45 & $17,92^{\mathrm{b}}$ & $5,00^{\mathrm{b}}$ & $-1,43$ & 1,32 & 0,00 & \multirow{2}{*}{$\begin{array}{r}U=739,00 \\
Z=-1,07\end{array}$} & \multirow{2}{*}{0,28} & \multirow{2}{*}{0,12} \\
\hline & $\mathrm{KS}$ & 38 & $16,80^{\mathrm{b}}$ & $4,24^{b}$ & $-1,30$ & 2,54 & 0,00 & & & \\
\hline \multirow{2}{*}{$\begin{array}{l}\text { Izkušnje učenja iz } \\
\text { e-gradiv }{ }^{\mathrm{a}}\end{array}$} & ES & 45 & 0,11 & 0,94 & $-0,28$ & $-0,15$ & 0,73 & \multirow{2}{*}{$t(81)=1,12$} & \multirow{2}{*}{0,27} & \multirow{2}{*}{0,12} \\
\hline & $\mathrm{KS}$ & 38 & 0,13 & 1,06 & 0,29 & $-0,35$ & 0,45 & & & \\
\hline \multirow{2}{*}{ Predznanje } & ES & 45 & $30,15^{\mathrm{b}}$ & $4,08^{b}$ & $-1,01$ & 1,51 & 0,01 & $U=762,00$ & \multirow{2}{*}{0,39} & \multirow{2}{*}{0,07} \\
\hline & $\mathrm{KS}$ & 38 & $29,50^{\mathrm{b}}$ & $3,57^{\mathrm{b}}$ & $-0,50$ & 0,57 & 0,16 & $Z=-0,86$ & & \\
\hline
\end{tabular}

Opombe. $M$ - aritmetična sredina, $M d n$ - mediana, $S D$ - standardni odklon, $I Q R$ - interkvartilni razmik (razlika med tretjim in prvim kvartilom), $A s$ - koeficient asimetrije, $S p l$ - koeficient sploščenosti, $S$ - $W$ - $p$-vrednosti Shapiro-Wilk testa normalnosti porazdelitve, Test - vrednosti Studentovega $t$-testa za spremenljivke z normalno porazdelitvijo ali Mann-Whitneyevega $U$-testa za spremenljivke z nenormalno porazdelitvijo, $r$ - Pearsonov koeficient kot mera velikosti učinka.

a Vrednosti temeljijo na komponentnih dosežkih dijakov.

${ }^{\mathrm{b}}$ Vrednosti mediane in interkvartilnega razmika pri spremenljivkah z nenormalno porazdelitvijo. 
Tabela 2. Opisne statistike ter analiza učne uspešnosti in uporabe elementov e-učbenika dijakov ES in KS

\begin{tabular}{llcrrrrrrrr}
\hline & & $N$ & $M / M d n$ & $S D / I Q R$ & $A s$ & $S p l$ & $S-W$ & \multicolumn{1}{c}{ Test } & $p$ \\
\hline \multirow{2}{*}{ Učna uspešnost } & $\mathrm{ES}$ & 45 & 22,98 & 4,73 & $-0,33$ & $-0,53$ & 0,42 & \multirow{2}{*}{$t(81)=2,43$} & 0,02 & 0,26 \\
Uporaba elementov & $\mathrm{KS}$ & 38 & 20,39 & 4,96 & $-0,13$ & $-0,99$ & 0,29 & & \\
e-učbenika & $\mathrm{ES}$ & 45 & $14,08^{\mathrm{a}}$ & $3,66^{\mathrm{a}}$ & 0,43 & $-0,89$ & 0,06 & $U=695,00$ & 0,79 & 0,03 \\
\hline
\end{tabular}

Opombe. $M$ - aritmetična sredina, $M d n$ - mediana, $S D$ - standardni odklon, $I Q R$ - interkvartilni razmik (razlika med tretjim in prvim kvartilom), $A s$ - koeficient asimetrije, $S p l$ - koeficient sploščenosti, $S$ - $W-p$-vrednosti Shapiro-Wilk testa normalnosti porazdelitve, Test - vrednosti Studentovega $t$-testa za spremenljivke z normalno porazdelitvijo ali Mann-Whitneyevega $U$-testa za spremenljivke z nenormalno porazdelitvijo, $r$ - Pearsonov koeficient ko mera velikosti učinka.

${ }^{a}$ Vrednosti mediane in interkvartilnega razmika pri spremenljivkah z nenormalno porazdelitvijo.

Po končanem reševanju preizkusa znanja so dijaki ocenili še lastno učno uspešnost na preizkusu znanja ter poročali o težavnosti in zanimivosti učne snovi. Vrednosti MannWhitneyjevega $U$-testa, prikazane v tabeli 3 , niso pokazale pomembnih razlik med dijaki ES in KS $\mathrm{v}$ nobeni izmed merjenih spremenljivk - niti v zaznani učni uspešnosti niti v zaznani težavnosti in zanimivosti učne snovi. Še največja je bila razlika med dijaki v zaznani učni uspešnosti. Razlika v mediani med skupinama je bila 0,24 točke, kar nakazuje, da so se dijaki ES zaznavali kot nekoliko bolj učno uspešni, medtem ko so bile razlike med ES in KS v zaznani težavnosti in zanimivosti učne snovi nične $(0,04$ in 0,09$)$.

\section{Razprava}

Z raziskavo smo želeli ugotoviti, ali lahko navodila učiteljic o spretni uporabi e-učbenika ter njegovih multimedijskih in interaktivnih elementov pri učenju pomagajo dijakom $\mathrm{k}$ uspešnejšemu samostojnemu učenju iz e-gradiv in boljšemu razumevanju učne snovi.

Dijake obeh skupin smo pred eksperimentom poskušali izenačiti v spremenljivkah, relevantnih za uspešnost učenja $\mathrm{v}$ e-učnem okolju, na katere opozarjajo predhodne raziskave (Cakir in Solak, 2014; Gegenfurtner idr., 2011; Luik in Mikk, 2008; Mbarek in El Gharbi, 2013; Nishizaki, 2015; Núñez

Tabela 3. Primerjava zaznane učne uspešnosti, težavnosti in zanimivosti učne snovi pri dijakih $E S$ in $K S$

\begin{tabular}{|c|c|c|c|c|c|}
\hline & $M d n$ & $I Q R$ & Test & $p$ & $r$ \\
\hline \multicolumn{6}{|c|}{$\begin{array}{l}\text { Zaznana učna } \\
\text { uspešnost }\end{array}$} \\
\hline ES & 3,14 & 1,50 & $U=643,0$ & \multirow{2}{*}{0,39} & \multirow{2}{*}{0,09} \\
\hline $\mathrm{KS}$ & 2,90 & 1,35 & $Z=-0,86$ & & \\
\hline \multicolumn{6}{|c|}{$\begin{array}{l}\text { Zaznana težavnost } \\
\text { učne snovi }\end{array}$} \\
\hline ES & 2,43 & 1,49 & $U=703,0$ & \multirow{2}{*}{0,85} & \multirow{2}{*}{0,02} \\
\hline KS & 2,39 & 1,70 & $Z=-0,19$ & & \\
\hline \multicolumn{6}{|c|}{$\begin{array}{l}\text { Zanimivost učne } \\
\text { snovi }\end{array}$} \\
\hline $\mathrm{ES}$ & 3,10 & 1,37 & $U=764,0$ & \multirow{2}{*}{0,62} & \multirow{2}{*}{0,05} \\
\hline $\mathrm{KS}$ & 3,19 & 1,42 & $Z=0,50$ & & \\
\hline
\end{tabular}

Opombe. $M d n$ - mediana, $I Q R$ - interkvartilni razmik (razlika med tretjim in prvim kvartilom), Test - vrednosti Mann-Whitneyevega

$U$-testa, $r$ - Pearsonov koeficient kot mera velikosti učinka. idr., 2011). Dobljeni rezultati raziskave nakazujejo, da lahko $\mathrm{z}$ veliko verjetnostjo trdimo, da obstaja pomemben vpliv navodil učiteljic na učno uspešnost dijakov $\mathrm{v}$ modernem in tehnološko podprtem e-učnem okolju, kar ugotavljajo tudi druge študije (Mbarek in El Gharbi, 2013; Poznič in Pečjak, 2017; Song in Kang, 2012). Dijaki ES, ki so v raziskavi prejeli navodila učiteljic o spretnem upravljanju z multimedijskimi in interaktivnimi elementi e-učbenika, so se v nasprotju z dijaki KS, ki teh navodil niso prejeli, odrezali pomembno bolje na preizkusu znanja po učenju iz izbrane enote e-učbenika, pri čemer lahko govorimo o srednje velikem učinku $(r=$ $0,26)$. Dejstvo je, da so manjše razlike med skupinama pred eksperimentom obstajale in so bile v prid dijakom ES. Dijaki ES so že pred začetkom eksperimenta poročali o nekoliko pogostejši uporabi učnih strategij, pokazali so nekaj več predznanja s področja geografije in poročali o več izkušnjah učenja ize-gradiv. Statističnitestipa so kljub manjšim razlikam v omenjenih povprečnih vrednostih potrdili izenačenost dijakov ES in KS v teh spremenljivkah. Na podlagi tega bi lahko $\mathrm{z}$ veliko verjetnostjo trdili, da je bila ključna razlika $\mathrm{v}$ eksperimentalnem načrtu med obema skupinama dijakov samo v navodilih učiteljic, ki so jih ti dobili.

Kot je razvidno iz rezultatov, so dijaki ES v primerjavi $\mathrm{z}$ vrstniki KS nekoliko več uporabljali multimedijske in interaktivne elemente e-učbenika, ki sta jih v ES posebej poudarili učiteljici. Dobljeni rezultati kažejo večjo razpršenost $\mathrm{v}$ uporabi e-elementov pri učencih KS oz. večjo homogenost učencev ES pri rabi e-elementov. Rezultati nakazujejo na sklep, da je boljši rezultat dijakov na preizkusu znanja verjetno posledica natančnih navodil učiteljice o značilnostih multimedijskih in interaktivnih elementov eučbenika. Ti so bili namreč nosilci relevantne učne vsebine, ki smo jo preverjali s preizkusom znanja. To pomeni, da so morali dijaki odpreti določene hiperpovezave v učni snovi, pogledati določene slike in simulacije ter se bolj usmeriti na pomembne učne vsebine/pojme, zapisane $\mathrm{v}$ okvirjih, da so lahko pravilno odgovorili na testna vprašanja. Ta razlika $\mathrm{v}$ uporabi multimedijskih in interaktivnih elementov je bila res zelo majhna, predpostavljamo pa, da bi lahko ob popolni izenačitvi ES in KS (npr. po metodi identičnih parov) ter ob pogostejšem samostojnem učenju dijakov iz e-učbenika ob podpornih navodilih učiteljice pričakovali porast uporabe teh elementov. Uporaba katere koli strategije - tudi strategije spretnega upravljanja $\mathrm{z}$ multimedijskimi in interaktivnimi elementi e-učbenika - je namreč povezana s pogostostjo uporabe te strategije. $\mathrm{V}$ našem eksperimentu sta učiteljici 
dijakom skozi navodila predstavili to strategijo, pri čemer so ti dobili le enkratno priložnost za njeno uporabo.

Ob tem se lahko navežemo tudi na zaznave dijakov o zanimivosti in težavnosti učne snovi, o čemer so poročali po učenju. Obe skupini dijakov (ES in KS) sta po predelavi učne snovi to snov ocenili kot podobno zahtevno/težavno in podobno zanimivo. Pri zaznavi lastne uspešnosti na preizkusu znanja pa smo opazili, da so dijaki ES zaznavali nekoliko večjo uspešnost pri reševanju preizkusa znanja, kot je bilo to značilno za dijake KS, čeprav se ta razlika ni pokazala kot statistično značilna. Tak rezultat morda nakazuje, da so dijaki, ki so prejeli natančnejša navodila učiteljic, nekoliko pogosteje dostopali do relevantnih učnih vsebin in jim namenili več pozornosti, kar se je nadalje mogoče odrazilo v tem, da so imeli po reševanju preizkusa znanja »boljši občutek«. Ta subjektivna zaznava večje učne uspešnosti na preizkusu znanja pri dijakih ES pa ima lahko podlago v dejansko boljšem učnem dosežku na tem preizkusu. Znano je, da so dijaki v tem starostnem obdobju sposobni precej realno evalvirati lastno učno uspešnost, kar je ena izmed pomembnih samoregulacijskih spretnosti pri samostojnem učenju (van der Stel in Veenman, 2010; Zimmerman, 2002).

V raziskavi stabili učiteljici ES, ki sta dali dijakom natančna navodila o spretni uporabi multimedijskih in interaktivnih elementov e-učbenika, postavljeni $\mathrm{v}$ vlogo trenerk veščin dela $\mathrm{z}$ e-učbenikom, kar avtorji poudarjajo kot eno izmed ključnih vlog učiteljev v modernih e-učnih okoljih (Anderson idr., 2001; McGhee in Kozma, 2001). Takšno neposredno učenje veščin dela $\mathrm{z}$ e-gradivom omogoča učencem večjo učno uspešnost (Nishizaki, 2015), čemur lahko pritrdimo tudi mi z našimi ugotovitvami. Po socialni kognitivni teoriji in ideji modelnega učenja (Bandura, 1986) sta imeli učiteljici v ES vlogo realnega in mojstrskega modela, pri katerem gre za kognitivno modeliranje in podajanje ustnih usmeritev.

Poleg značilnosti učitelja in učencev je pomemben dejavnik uspešnosti pri e-učenju tudi značilnost e-učbenika, iz katerega poteka učenje. Ustrezno oblikovan in kakovosten e-učbenik je temelj za uspešno učno delo (Kreuh idr., 2011). Zaradi tega smo posebno pozornost posvetili izbiri e-učbenika, ki bi bil oblikovan po načelih procesiranja multimedijskega gradiva skladno s kognitivno teorijo multimedijskega učenja (Mayer, 2009, 2013). V e-gradivu, ki smo ga uporabili $\mathrm{v}$ raziskavi, so bile predstavljene bistvene informacije, imeli smo ustrezno količino besedila in vizualnega gradiva (slik in animacij), gradivo je bilo predstavljeno v smiselnem sosledju, poudarjene so bile tudi ključne besede. Izbrana učna enota V naši raziskavi je imela tudi nekaj elementov, ki jih kot potrebne navajata Gagné in Medsker (1996), npr. navezovanje na predznanje, usmerjanje dijakov, vaja, torej elemente, ki olajšujejo samostojno učenje dijakov (Driscoll, 2005; Leow in Neo, 2014; Martin, Klein in Sullivan, 2004). Primernost izbranega e-učbenika so posredno potrdili tudi dijaki ES in KS, saj so navajali, da razumevanje učne snovi ni bilo zahtevno. Zdi se, da dijaki niso imeli težav s preklapljanjem med besedilom ter multimedijskimi in interaktivnimi elementi e-učbenika. Sklenemo lahko, da smo z raziskavo pokazali, da so dijaki lahko učno uspešnejši, če jim učitelj poda nekatere usmeritve dela $\mathrm{z}$ multimedijskimi in interaktivnimi elementi v e-učbeniku.

\section{Zaključki, omejitve in uporaba raziskovalnih ugotovitev}

Izbrana študija je aktualna in relevantna, saj po eni strani narašča obseg učenja iz e-učbenikov v šolskem kontekstu in doma, po drugi strani pa je to razmeroma nov, še premalo raziskan kontekst učenja, še posebej v povezavi z različnimi oporami učitelja za večjo učno uspešnost učencev. V raziskavi smo skladno z izbrano eksperimentalno metodo in ustreznimi statističnimi postopki potrdili izhodiščno predpostavko, da imajo natančnejša navodila učiteljic pozitiven učinek na učne dosežke dijakov pri učenju iz e-učbenika. Upoštevanje te ugotovitve je pomembno za vse situacije, ko se učenci v šoli samostojno učijo iz e-gradiv. Kaže namreč, da učiteljevo usmerjanje $\mathrm{k}$ spretnemu delu $\mathrm{z}$ elementi $\mathrm{v}$ e-gradivu pomaga dijakom $\mathrm{k}$ boljšemu procesiranju učnih vsebin in $\mathrm{h}$ končnemu učnem dosežku. Smiselno se nam zdi nadaljnje raziskovanje vpliva različnih učiteljevih navodil (strateških, metakognitivnih in motivacijskih [Belland, 2017]) na učno uspešnost učencev. Zanimivo bi bilo preučiti učinek posamičnih in kombiniranih opor oziroma navodil. Če bodo raziskave tudi $\mathrm{v}$ prihodnje potrdile pozitivno povezanost opor/navodil in učne uspešnosti, bo to pomembno didaktično spoznanje za učitelje, kako vključevati e-učbenik v učni proces.

Izvedena raziskava ima več omejitev, zato lahko sklenemo, da so rezultati predvsem indikativni - nakazujejo, da lahko z navodili učitelja pri uporabi e-učbenikov zelo verjetno izboljšamo učno uspešnost učencev. V smeri večje posplošljivosti rezultatov pa bi veljalo v nadaljnjem raziskovanju preseči nekatere šibkosti študije. Smiselno bi bilo izvesti nadaljnjo validacijo $\mathrm{v}$ raziskavi uporabljenih vprašalnikov, še zlasti to velja za Vprašalnik motivacijskih prepričanj in učnih strategij, katerega struktura je še vedno predmet raziskav, pa tudi drugih vprašalnikov, ki smo jih oblikovali sami. S sorazmerno majhnim vzorcem naše raziskave ni bilo mogoče opraviti analize, ki bi omogočila dovolj zaupanja $\mathrm{v}$ veljavnost preučevanih konstruktov. $Z$ večjim vzorcem bi analiza podatkov omogočila večjo statistično moč testov in večje zaupanje v velikosti učinkov. Vsebinsko ustreznost preizkusa znanja bi lahko poleg učiteljic, ki sta sodelovali v raziskavi, pred uporabo preverili še drugi učitelji geografije, s čimer bi nadzorovali še enega izmed dejavnikov variabilnosti odvisne spremenljivke. Nadalje bi se nam zdelo $\mathrm{v}$ raziskovanju $\mathrm{v}$ prihodnje smiselno podaljšati čas izvedbe eksperimenta. Pri nas je celoten eksperiment trajal 45 minut - 5 minut za navodila učiteljice, 20 minut za samostojno učenje dijakov in 20 minut za reševanje preizkusa znanja. Predvidevamo, da bi daljši čas učenja in reševanja preizkusa znanja omogočil bolj avtentično, tj. natančnejše in bolj poglobljeno učenje. Pri daljšem učenju pa bi lahko dijaki tudi bolje izkoristili specifična navodila učiteljice o uporabi multimedijskih in interaktivnih elementov iz učne snovi. Zastavljen raziskovalni problem naše raziskave bi bilo mogoče razširiti v različne smeri, in sicer preučiti: 1) učinkovitost e-učenja pri drugih šolskih predmetih (mi smo to naredili pri geografiji); 2) učenje $\mathrm{z}$ različnimi multimedijskimi in interaktivnimi elementi $v$ e-učbenikih (npr. raziskati še prisotnost videa ali zahtevnejših animacij in simulacij (Wu, 
Chang, Chen, Yeh in Liu, 2010); 3) vpliv različnih oblik in metod dela $\mathrm{z}$ e-učbeniki (npr. primerjati vpliv učiteljevih navodil pri samostojnem delu dijakov in učenju teh $\mathrm{v}$ paru) (Rebetez, Betrancourt, Sangin in Dillenbourg, 2010).

Ker sta poučevanje in učenje procesa, ki zahtevata aktivnega učitelja (kot poudarja Gagnéjeva teorija poučevanja; Driscoll, 2005; Gagné in Medsker, 1996) in aktivnega učenca (kot poudarja teorija samoregulacijskega učenja; Zimmerman, 2002), bi bila potrebna podrobnejša raziskava značilnosti učiteljev in tudi drugih značilnosti učencev pri samostojnem učenju iz e-učbenikov (npr. sposobnosti učencev, njihovih izobrazbenih aspiracij in aspiracij njihovih staršev; Song in Kang, 2012).

\section{Literatura}

Anderson, L.W. in Krathwohl, D. R. (ur.). (2001). A taxonomy for learning, teaching, and assessing: A revision of Bloom's taxonomy of educational objectives. Boston, MA, ZDA: Allyn and Bacon.

Anderson, T., Rourke, L., Garrison, R. in Archer, W. (2001). Assessing teaching presence in a computer conferencing context. Journal of Asynchronous Learning Networks, 5(2), 1-17.

Ballera, M., Lukandu, I. A. in Radwan, A. (2014). Improving learning throughput in e-learning using interactivecognitive based assessment. The International Journal of E-Learning and Educational Technologies in the Digital Media, 1(1), 32-49.

Bandura, A. (1986). Social foundations of thought and action: A social-cognitive theory. Englewood Cliffs, NJ, ZDA: Prentice Hall.

Belland, B. R. (2017). Instructional scaffolding in STEM education: Strategies and efficacy evidence. Pridobljeno s https://link.springer. $\mathrm{com} /$ content/pdf/10.1007\%2F978-3-319-02565-0.pdf

Berg, S. A., Hoffmann, K. in Dawson, D. (2010). Not on the same page: Undergraduates' information retrieval in electronic and print books. The Journal of Academic Librarianship, 36(6), 518-525.

Cakir, R. in Solak, E. (2014). Exploring the factors influencing e-learning of Turkish EFL learners through TAM. The Turkish Online Journal of Educational Technology, 13(3), 79-87.

Cho, M. H. in Summers, J. (2012). Factor validity of the Motivated Strategies for Learning Questionnaire (MSLQ) in Asynchronous Online Learning Environments (AOLE). Journal of Interactive Learning Research, 23(1), 5-28.

Costley, J. in Lange, C. (2016). The effects of instructor control of online learning environments on satisfaction and perceived learning. The Electronic Journal of $e$ Learning, 14(3), 169-180.

Costley, J. in Lange, C. (2017). The mediating effects of germane cognitive load on the relationship between instructional design and students' future behavioral intention. The Electronic Journal of e-Learning, 15(2), 174-187.

Credé, M. in Phillips, L. A. (2011). A meta-analytic review of the Motivated Strategies for Learning Questionnaire. Learning and Individual Differences, 21(4), 337-346.
Daniel, D. B. in Woody, W. D. (2012). E-textbooks at what cost? Performance and use of electronic vs. print texts. Computers \& Education, 62, 18-23.

Dobler, E. (2015). E-textbooks: A personalized learning experience or digital distraction? Journal of Adolescent \& Adult Literacy, 58(6), 482-491.

Driscoll, M. P. (2005). Psychology of learning for instruction: Pearson new international edition. Harlow, Združeno kraljestvo: Pearson Education.

Ebied, M. M. A. in Rahman, S. A. A. (2015). The effect of interactive e-book on students' achievement at Najran University in computer in education course. Journal of Education and Practice, 6(19), 71-82.

Gagné, R. M. in Medsker, K. L. (1996). The conditions of learning: Training applications. Fort Worth, TX, ZDA: Harcourt Brace College Publishers.

Gegenfurtner, A., Lehtinen. E. in Säljö, R. (2011). Expertise differences in the comprehension of visualizations: A meta-analysis of eye-tracking research in professional domains. Education Psychology Review, 23(4), 523-552.

Hilpert, J. C., Stempien, J., van der Hoeven Kraft, K. J. in Husman, J. (2013). Evidence for the latent factor structure of the MSLQ: A new conceptualization of an established questionnaire. SAGE Open. Pridobljeno s http://sgo. sagepub.com/content/3/4/2158244013510305

Hwang, G. H., Chen, B. in Huang, C. W. (2016). Development and effectiveness analysis of a personalized ubiquitous multidevice certification tutoring system based on Bloom's taxonomy of educational objectives. Educational Technology \& Society, 19(1), 223-236.

Ivanišin, M. (2009). Nekateri strukturni in kulturni problemi pri uvajanju e-izobraževanja $\mathrm{z}$ nakazanimi rešitvami [Some structural and cultural problems and soulutions concerning e-education and its implementation]. Sodobna pedagogika, 60(2), 84-95.

Jones, T. in Brown, C. (2011). Reading engagement: A comparison between e-books and traditional print books in an elementary classroom. International Journal of Instruction, 4(2), 5-22.

Kreuh, N., Kač, L. in Mohorčič, G. (2011). Izhodišča za izdelavo e-učbenikov [Framework for the design of electronic textbooks]. Ljubljana, Slovenija: Zavod Republike Slovenije za šolstvo.

Lawanto, O., Santoso, H. B., Goodridge, W. in Lawanto, K. N. (2014). Task value, self-regulated learning, and performance in a web-intensive undergraduate engineering course: How are they related? MERLOT Journal of Online Learning and Teaching, 10(1), 97-111.

Leow, F. T. in Neo, M. (2014). Interactive multimedia learning: Innovating classroom education in a Malaysian University. The Turkish Online Journal of Educational Technology, 13(2), 99-110.

Lipovec, A., Senekovič, J. in Repolusk, S. (2014). Načini uporabe i-učbenika [How to use an i-textbook]. V I. Pesek, B. Zmazek in V. Milekšič (ur.), Slovenski $i$ učbeniki [Sloevian i-textbooks] (str. 117-143). Ljubljana, Slovenija: Zavod Republike Slovenije za šolstvo.

Luik, P. in Mikk, J. (2008). What is important in electronic textbooks for students of different achievement levels? Computer \& Education, 50(4), 1483-1494. 
Martin, F., Klein, J. in Sullivan, H. (2004). Effects of instructional events in computer based instruction. V M. Simonson in M. Crawford (ur.), 27th annual proceedings of selected research and development papers (str. 631-639). Chicago, IL, ZDA: Association for educational communications and technology conference. Pridobljeno s strani http://files.eric.ed.gov/fulltext/ ED484984.pdf

Mayer, R. E. (2009). Multimedia learning. New York, NY, ZDA: Cambridge University Press.

Mayer, R. E. (2013). Učenje s tehnologijo [Learning with technology]. V H. Dumont, D. Istance in F. Benavides (ur.), O naravi učenja: uporaba raziskav za navdih prakse [On the nature of learning: using research for inspiration in praxis] (str. 163-181). Ljubljana, Slovenija: Zavod RS za šolstvo.

Mayer, R. E., Mathias, A. in Wetzell, K. (2002). Fostering understanding of multimedia messages through pretraining: Evidence for a two-stage theory of mental model construction. Journal of Experimental Psychology Application, 8(3), 147-154.

Mbarek, R. in El Gharbi, J. E. (2013). A meta-analysis of elearning effectiveness antecedent. International Journal of Innovation and Applied Studies, 3(1), 48-58.

McGhee, R., in Kozma, R. (2001). New teacher and student roles in the technology-supported classroom. A paper presented at the Annual meeting of the American Educational Research Association, April 2001, Seattle, WA, ZDA. Pridobljeno s strani http://www.cehd.umn. edu/carei/publications/documents/newrolestechnology. pdf

Nishizaki, D. M. (2015). The effects of tablets on learning: Does studying from a tablet computer affect student learning differently across educational levels. Senior thesis, Claremont McKenna College, Claremont, CA, ZDA. Pridobljeno s strani http://scholarship.claremont. edu/cmc theses/1011

Núñez, J. C., Cerezo, R., Bernardo, A., Rosário, P., Valle, A., Fernández, E. in Suárez, N. (2011). Implementation of training programs in self-regulated learning strategies in Moodle format: Results of a experience in higher education. Psicothema, 23(2), 274-281.

Pintrich, P. R., Smith, D. A. F., Garcia, T. in McKeachie, W. J. (1991). A manual for the use of the Motivated Strategies for Learning Questionnaire (MSLQ). Ann Arbor, MI, ZDA: University of Michigan. Pridobljeno s strani http:// files.eric.ed.gov/fulltext/ED338122.pdf

Poznič, A. (2016). Vpliv učiteljevih navodil na učno uspeřnost dijakov pri učenju z elektronskimi učbeniki (neobjavljeno magistrsko delo) [The effect of the teacher's instructions on the academic achievement of high school students in learning with electronic textbooks (unpublished MA thesis)]. Filozofska fakulteta Univerze v Ljubljani, Slovenija.
Poznič, A. in Pečjak, S. (2017). Značilnosti dijakov v povezavi z njihovo učno uspešnostjo pri e-učenju. [Characteristics of students and learning environment in connection with e-learning success]. Pedagoška obzorja, 32(1), 111-125.

Rebetez, C., Betrancourt, M., Sangin, M. in Dillenbourg, P. (2010). Learning from animation enabled by collaboration. Instructional Science, 38(5), 471-485.

Rockinson-Szapkiw, A. J., Courduff, J., Carter, K. in Bennett, D. (2013). Electronic versus traditional print textbooks: A comparison study on the influence of university students' learning. Computers \& Education, 63, 259-266.

Rutar Leban, T. in Milekšič, V. (2016). Evalvacijska študija pilotnih projektov uporabe e-učbenikov v osnovnih šolah in gimnazijah [An evaluation study of the pilot projects of the use of e-textbooks in primary schools and secondary schools]. V A. Sambolić Beganović in A. Čuk (ur.), Kaj nam prinaša e-Šolska torba II: Primeri obetavnih praks in evalvacija projekta [What is an e-schoolbag bringing to us: Good practices and project eveluation] (str. 175205), Ljubljana, Slovenija: Zavod Republike Slovenije za šolstvo.

Shih, C.-C. in Gamon, J. A. (2002). Relationships among learning strategies, patterns, styles, and achievement in web-based courses. Journal of Agricultural Education, 43(4), 1-11.

Song, H. D. in Kang, T. (2012). Evaluating the impacts of ICT use: A multi-level analysis with hierarchical linear modeling. The Turkish Online Journal of Educational Technology, 11(4), 132-140.

Uluyol, Ç. in Şahin, S. (2014). Elementary school teachers' ICT use in the classroom and their motivators for using ICT. British Journal of Educational Technology, 47(1), 65-75.

van der Stel, M. in Veenman, M. V. J. (2010). Development of metacognitive skillfulness: A longitudinal study. Learning and Individual Differences, 20(3), 220-224.

Van Horne, S., Russell, J. E. in Schuh, K. L. (2016). The adoption of mark-up tools in an interactive e-textbook reader. Educational Technology Research and Development, 64(3), 407-433.

Wells, C. L. (2012). Do students using electronic books display different reading comprehension and motivation levels than students using traditional print books? Doctoral dissertation, Liberty University, Lynchburg, VA, ZDA. Pridobljeno s strani http://digitalcommons. liberty.edu/doctoral/623/

Wu, H. C., Chang, C. Y., Chen, C. L. D., Yeh, T. K. in Liu, C. C. (2010). Comparison of earth science achievement between animation-based and graphic-based testing designs. Research in Science Education, 40(5), 639-673.

Zimmerman, B. J. (2002). Becoming a self-regulated learner: An overview. Theory Into Practice, 41(2), 64-70. 